\title{
AFFIXATION SYSTEM OF BALINESE LANGUAGE SPOKEN BY MUSLIM PEOPLE IN TEGALLINGGAH VILLAGE: A DESCRIPTIVE QUALITATIVE STUDY
}

\author{
K. Suardika ${ }^{1}$, I G. Budasi ${ }^{2}$, G.A.P. Suprianti ${ }^{3}$ \\ Jurusan Pendidikan Bahasa Inggris, Fakultas Bahasa dan Seni \\ Universitas Pendidikan Ganesha, Singaraja, Bali, Indonesia \\ E-mail: kadeksuardika225@gmail.com¹,gede.budasi@undiksha.ac.id², gap.suprianti@undiksha,.ac.id ${ }^{3}$
}

\begin{abstract}
ABSTRAK
Penelitian ini bertujuan untuk mendeskripsikan imbuhan: awalan dan akhiran bahasa Bali yang digunakan oleh warga Muslim di Desa Tegallinggah yang tergolong kedalam morfem derifasi dan morfeminfleksi. Penelitian deskriptif kualitatif ini melibatkan tiga informan yang dipilih berdasarkan satu set kriteria. Data dikumpulkan berdasarkan tehnik observasi, perekaman, dan wawancara. Instrumenpada penelitian ini terdiri dari 2 kategori: instrument utama (peneliti) dan intrumen pendukung (daftar kata, lembar observasi alat perekam digital, dan kamera). Tiga proses dalam menganalisis data diantaranya pemilahan, penyajian dan penyimpulan data.Hasil penelitian menunjukan adanyasembilanawalan danenam akhiran bahasa Bali yang digunakan oleh warga Muslim di Desa Tegallinggah. Kesembilan awalanyang dimaksud dapat diklasifikasikan menjadi :2 awalan $\{$ mə-\} dan $\{$ nən- $\}$ yang hanya tergolong morfem derifasi, 4 awalan $\{\Lambda-\},\{\mathrm{k} ə-\},\{\mathrm{b}-\}$, dan $\left\{\mathrm{o}^{-}\right\}$yang hanya tergolong morfem infleksi,; 3 awalan $\{\mathrm{n}-\},\{\mathrm{n}-\}$, dan $\{\mathrm{m}-\}$ yang bisa tergolong morfem derifasi dan morfem infleksi: selanjutnya, keenam akhiran yang dimaksud dapat diklasifikasinkan sebagai berikut; tidak ada akhiran yang hanya tergolong morfem derifasi; 4 akhiran $\{-\overline{\mathrm{e}}\},\{-\partial\},\{-\Lambda \mathrm{y}\}$, dan $\{-\mathrm{In}\}$ yang hanya tergolong morfem infleksi; 2 akhiran $\{-\Lambda \mathrm{n}\}$, dan $\{-\mathrm{n}\}$ yang bisa tergolong morfem derifasi dan morfem inlfeksi.
\end{abstract}

Kata-kata kunci: awalan, akhiran, bahasa Bali, morfem derivasi, morfen infleksi

\section{ABSTRACT}

This study aimed at describing the affixes: prefixes and suffixes of Balinese language spoken by Muslim people which belong to derivational and inflectional morpheme. This descriptive qualitative study involved 3 informants chosen based on a set criteria. The gained data were collected through observing, recording, and interviewing technique. The instruments in this study were classified into: main instrument (the researcher) and secondary instruments (word list, observation sheet, digital recorder, and camera). The three processes in analyzing the data were data reduction, data display, and data conclusion or verification. This study revealed nine prefixes and six suffixes of Balinese language spoken by Muslim people in Tegallinggah Village. The nine prefixes are classified into: 2 prefixes \{ma\} and $\{n \partial y-\}$ which belong only to derivational morpheme, 4 prefixes $\{\Lambda\},\{k \partial-\},\{b \partial\}$, and $\{a-\}$, belong only to inflectional morpheme, 3 prefixes $\{\eta-\},\{\eta-\}$, and $\{m-\}$ can belong to derivational and inflectional morpheme. Afterward, the six suffixes are classified into; there is no suffix which belong only to derivational morpheme, 4 suffixes $\{-\bar{e}\},\{-\partial\},\{-\Lambda \eta\}$, and $\{-I n\}$ belong only to inflectional morpheme, 2 suffixes $\{-\wedge n\}$, dan $\{-n\}$ can belong to derivational and inflectional morpheme.

Key Words: prefixes, suffixes, Balinese language, derivational morpheme, inflectional morpheme 


\section{INTRODUCTION}

Language and human cannot be separated with each other. A language is considered as a system of communication which uses sound symbols and words in order to express meaning, idea or thought (Kracht, 2007). According to Rickford, Sweetland, and Rickford (2004), language is a vital aspect of communication. Language conveys meaning through the contents of words and sentences (Wagner, Clopper, \& Pate, 2014). People talk about all sorts of things in their lives, discuss various problems, do businesses, show concerns, present ideas, express feelings, and produce various kinds of writings by using language (Seken, 2017).

There are thousand languages in the world. The difference across languages which refers to multilingualism is a common and natural phenomenon (Holmes, Wardhaugh, cited in Tegegne, 2015). However, the diversity of language is not only about multilingualism, but there are also variations within a language (Tegegne, 2015). It is Dialect which refers to a variation of a language that shows the characteristics of the speakers of that language (Flores, 2006). It is also defined as a regional or social variety of a language which is distinguished by pronunciation, grammar, or vocabulary, especially a way of speaking that differs from the standard variety of the language (Yule, 2006).

One of the languages which has some dialects with great historical process is $\mathrm{Ba}-$ linese language(Surada, 2015). The variation of Balinese language is classified into 2 dialects: Bali Aga dialect and Bali Dataran dialect (Bawa and Jendra, 1981). One of the unique Bali Dataran dialects occurs in Tegallinggah village, Sukasada sub-district, Buleleng regency, North Bali. Based on the preliminary observation, the characteristics of Tegalinggah village are different from other villages. It is its Muslim population and geographic area. 45 $\%$ of the populations in Tegallinggah village are Muslim and the rest are Hindus. It means that the population of Muslim people in this village is quite big. Furthermore, geographi- cally Tegallinggah village is divided into three areas; upper, middle, and the lower area. Most of the Muslims populations live in the middle area, while the Hindus are in the upper area and lower area. The Muslim people in this village are not isolated. They have a good communication and interaction with the other villagers.

Moreover, it was found that the Muslims moved as migrant to Bali for long time ago. Theoretically, when someone or a group do a movement from one area to the other area, they will still consider with the sustain patterns of behavior and links to a homeland, to kin groups, to a shared past, and for a goal for the future (Cohen, Story, \& Moon, 2015). It means that the immigrant will use their own language to make a communication at least with their family or their group. Language is an identity of an ethnic or group and each ethnic or group has to preserve their culture through using their own language in their society or their group (Trudgill, 1974). However, it is slightly different from the Muslim people who live in Tegallinggah village. Based on the preliminary observation, it was found that Muslim people in Tegallinggah village use Balinese language as their colloquial languages.

It was also found that Muslim people in this village use the Balinese prefixes and suffixes when they communicate to the other. According to Carstairs \& McCarthy (2002), prefix is the affix which is attached in front of the root or stem; suffix is the affix which is attached at the end of the root or stem. The prefix and suffix can be classified into derivational morpheme and inflectional morpheme (Carstairs \& McCarthy, 2002). Derivational morpheme is a morpheme that changes the word class and the meaning of the stem. On the other hand, inflection morpheme refers to morphemes that change neither part of speech nor meaning, but only refinesand give extra grammatical information about the already existing meaning of a word (Carstairs \& McCarthy, 2002). During the process of Affixation, in some cases, it is followed by Assimilation process. Assimilation is a process of merging two different speech sounds to 
become similar Keraf (1980). The two kinds of assimilation are. Regressive and Progressive Assimilation. Regressive assimilation is the phoneme that comes first is affected by the one that comes after it. On the other hand, Progressive assimilation is the phoneme that come first affects the phoneme that come after it (Roach. 1991).

Some researchers have conducted the researches on morphology study especially affixation of Balinese language, such as: $\mathrm{Ku}-$ suma (2013); Utami (2013); Putra (2013); Wiweka (2014); Sudarma (2016); and Erlina (2017). However, there is no study that reveals the kinds of prefixes and suffixes of Balinese language which only belong to inflectional or derivational morpheme. There is no one conducting a study on morphology field especially Affixation of Balinese language in Tegallinggah village. This research can be seen as an effort to enrich the data related to prefixes and suffixes of Balinese language. Moreover, this study makes a serious effort to support previous studies in morphology field.

\section{METHOD}

The research design of this research was descriptive qualitative. The collected data take the form of words or pictures rather than numbers. Afterwards, the written results contain quotations from the data to illustrate the data clearly (Bogdan \& Biklen, 2007: p. 5).This study described the data related to prefixes and suffixes, inflectional and derivational morpheme of Balinese language spoken by Muslim people in Tegallinggah village. Three informants were involved in this study. The informants were selected through a set of criteria (Samarin, 1967). The data were gained through observation, recording, and interview technique. The instruments in this study are the researcher, wordlist (Swadesh and Nothofer), observation sheet, recorder, and camera.

There were some steps in the process of data collection, namely: preparing the instrument: doing the administrative permission to conduct the research in Tegallinggah village: asking suggestion to the head of the village: choosing and visiting the potential informant: observing the situation and language used of the informants; and interviewing the informant and take a record.

The gained data were analyzed qualitatively based on the theory proposed by Miles and Huberman (1984). The processes of data analysis in this study were data reduction, data display, and data conclusion/ verification. The first was data reduction. In this process, the researchers firstly identified the word classes and the meaning of the words that were gained from the informants. The next was identifying the changes of the word classes and the meaning of the words. Then, in data display process, the researchers divided and classified the data which have prefixes and suffixes which belong to derivational and or inflectional morpheme in form of table. The last was data conclusion. The researchers formulated the data, whether it is derivational or inflectional morpheme. The researchers concluded the result of the data display into findings and discussion.

The data were verified through methodological triangulation and data sources triangulation

\section{FINDINGS AND DISCUSSIONS}

This study revealed nine prefixes and six suffixes of Balinese language spoken by Muslim people in Tegallinggah Village. The nine prefixes are classified into: 2 prefixes $\{$ mə- $\}$ and $\{$ nəy- $\}$ belong only to derivational morpheme, 4 prefixes $\{\Lambda-\},\{\mathrm{k} ə-\},\{\mathrm{b} ə-\}$, and $\{\partial-\}$, belong only to inflectional morpheme, 3 prefixes $\{\mathrm{y}-\},\{\mathrm{n}-\}$, and $\{\mathrm{m}-\}$ can belong to derivational and inflectional morpheme. Afterward, the six suffixes are classified into; there is no suffix which belong only to derivational morpheme, 4 suffixes $\{-\bar{e}\},\{-\partial\},\{-\wedge \mathrm{y}\}$, and $\{-$ In $\}$ belong only to inflectional morpheme, 2 suffixes $\{-\Lambda \mathrm{n}\}$, and $\{-\mathrm{n}\}$ can belong to derivational and inflectional morpheme.

\section{The Prefixes and Suffixes that belong only to Derivational morpheme}

\section{Derivational Prefix}


In this study, the 2 prefixes that belong only to Derivational morpheme are prefix $\{\mathrm{m} ə-\}$ and $\{$ nəy- $\}$.

\section{Derivational Prefix $\{$ mə- $\}$}

Prefix $\{\mathrm{m} ə-\}$ has two forms when it is attached to a stem.

1. If the prefix $\{m o-\}$ is attached to the stem which is preceded by consonants $/ \mathrm{g} /, / \mathrm{b} /, \mathrm{c} / 1 /$, $/ \mathrm{j} /, / \mathrm{n} /, / \mathrm{k} /, / \mathrm{t} /, / \mathrm{d} /, / \mathrm{p} /, / \mathrm{s}, /$, and vowel $/ \mathrm{I} /, / \Lambda /$, and $/ \mho /$, the prefix can be directly added to the stem without changing the form of the stem.

$$
\begin{aligned}
& \text { mə }+\operatorname{gatth}(\mathrm{N}) \rightarrow \text { məgətih }(\mathrm{V}) \\
& \text { "blood" }
\end{aligned}
$$

The stem \{gətrh\} means 'blood' $(\mathrm{N})$. The prefix $\{\mathrm{mo}-\}$ changes the meaning of the stem from 'blood' $\rightarrow$ 'to lose blood'. It also changes the word class from Noun $\rightarrow$ Verb. In this case, the function of the prefix $\{\mathrm{mo}-\}$ is to indicate at loosing something.

2. On the other case, the prefix $\{$ mə- $\}$ also changes the form of the stem.

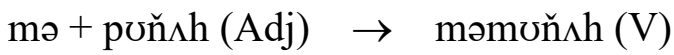

$$
\begin{aligned}
& \text { "drunken" "drink alcohol" }
\end{aligned}
$$

The stem \{poňsh\} means 'drunken' (Adj). The prefix $\{$ mə- $\}$ changes the form of the stem from $\{\mathbf{p} v$ ňsh $\} \rightarrow\{$ məmoň $\Lambda$ h $\}$. The prefix $\{\mathrm{m} ə-\}$ assimilates the stem. The stem undergoes Progressive Assimilation. The prefix $\{\mathrm{mo}\}$ also changes the meaning of the stem from 'drunken' $\rightarrow$ 'to drink much alcoholic drinks'. At the same time, the word class is also changed from Adjective $\rightarrow$ Verb. In this case, the function of the prefix $\{\mathrm{mo}\}$ is to indicate an active activity.

\section{Derivational Prefix \{nəy-\}}

Prefix $\{$ nəy- $\}$ is categorized into derivational morpheme since it changes the meaning and the word class of the stem.

$$
\text { nəy }+ \text { kıngın }(\mathrm{N}) \rightarrow \text { nəךkıngIn }(\mathrm{V})
$$$$
\text { "east" }
$$

The stem \{kıngin\} means 'east' (Noun). The prefix \{nəy- $\}$ changes the meaning from 'east' $\rightarrow$ 'go to the east'. The prefix \{nəy- $\}$ also changes the word class from Noun $\rightarrow$ Verb. The, the function of prefix $\{n \ni y-\}$ is to indicate the direction.

\section{Derivational Suffix}

Derivational morpheme is the morpheme which is used to form new words or to make words of a different grammatical category from the stem (Carstairs \& McCarthy, 2002). In this study, there is no suffix that belongs only to derivational morpheme.

\section{The Prefixes and Suffixes that belong only to Inflectional Morpheme}

\section{Inflectional Prefix}

In this study, there are 4 prefixes that belong only to Inflectional morpheme, which are prefix $\{\Lambda-\},\{\mathrm{k} ə-\},\{$ bə- $\}$, and $\left\{\partial^{-}\right\}$.

\section{Inflectional prefix $\{\Lambda-\}$}

Prefix $\{\Lambda-\}$ belongs to inflectional prefix

$$
\begin{aligned}
& \Lambda+\operatorname{bol} \Lambda n(\mathrm{~N}) \rightarrow \\
& \text { "month" }
\end{aligned} \quad \begin{aligned}
& \Lambda \mathrm{b} v \mathrm{l} \Lambda \mathrm{n}(\mathrm{N}) \\
& \text { "one month" }
\end{aligned}
$$

The stem $\{$ bol $\Lambda \mathrm{n}\}$ means 'month' $(\mathrm{N})$. After adding the prefix $\left\{\Lambda^{-}\right\}$, the meaning of the stem is 'one month' $(\mathrm{N})$. Basically, there is no different meaning between the stem $\{b o l \Lambda n\}$ and $\{\Lambda b o l \Lambda n\}$. However they have different context of used. The stem $\{\Lambda b \sigma l \Lambda n$ \} indicates a singular or one month. There is no change of the word class of the stem.

\section{Inflectional Prefix $\{k \boldsymbol{k}-\}$} prefix.

Prefix $\{\mathrm{k} ə-\}$ belongs to inflectional

$$
\begin{aligned}
& \text { kə }+\operatorname{tig} \Lambda \ln (\mathrm{V}) \rightarrow \\
& \text { "to see" }
\end{aligned}
$$

The stem $\{\operatorname{tin} \Lambda \operatorname{lin}\}$ means 'to see' (V). After adding the prefix $\{\mathrm{k} ə-\}$, the meaning of the stem is 'to see' (V). There is no change of 
the word class; it is Verb. Basically, there is no different meaning between the word 'tinslin' and 'kətin $\Lambda$ lin'. However, those words have a different context of used. The word 'tinslin' is usually used as a command. On the other hand, the word 'kətin $\Lambda$ lin' is usually used in an interrogative sentence.

\section{Inflectional prefix $\{$ bə- $\}$}

Prefix $\{b ə-\}$ belongs to inflectional prefix. The stem undergoes assimilation when the prefix $\{\mathrm{b}-\}$ is attached to the stem.

$$
\begin{aligned}
& \text { bə }+\mathrm{k} \wedge \mathrm{j} ə(\mathrm{~N}) \rightarrow \quad \text { bəd } \Lambda \mathrm{j} ə(\mathrm{~N}) \\
& \text { "south" }
\end{aligned}
$$

The stem $\{k \wedge j \ni\}$ means 'south' $(\mathrm{N})$. After adding the prefix $\{\mathrm{b} ə-\}$, the form of the stem changes from $\{\mathrm{k} \Lambda \mathrm{j} \partial\} \rightarrow\{$ bəd $\Lambda \mathrm{j} \partial\}$. The prefix $\{\mathrm{b} ə\}$ assimilates the stem $\{\mathrm{k} \Lambda \mathrm{j} \ni\}$ and it becomes $\{$ bəd $\Lambda j \ni\}$. The stem undergoes Progressive Assimilation. Basically, there is no different meaning between the word ' $k \wedge j ə$ ' and 'bəd $\Lambda$ jə'. However, those words have a different context of used. The word 'bəd $\Lambda$ jə' gives clearer information of a direction. The word ' $k \wedge j ə$ ' refers to a general direction of the south. However, the word 'bəd $\Lambda$ jə' refers to a specific direction of south which is known by the speaker and the listener. In this case, the function of prefix $\{b-\}$ is to indicate clear information of direction.

\section{Inflectional prefix $\{\boldsymbol{\theta}-\}$} prefix. Prefix $\{\partial-\}$ belongs to inflectional

$$
\begin{aligned}
& \text { ə }+ \text { nı }(\text { Adj) } \rightarrow \text { onı (Adj) } \\
& \text { "clear" "clear" }
\end{aligned}
$$

The stem $\{$ nin\}, means 'clear' (Adj). After adding the prefix $\{\partial-\}$, the meaning of the stem is 'so clear' (Adj). Basically, there is no different meaning between the word 'nın' and 'onin'. However, those words have a different context of used. The word 'onı' gives a higher degree of the clearness of something. In this case, the function of prefix $\{\partial-\}$ is to indicate a higher degree of something.

\section{Inflectional Suffix}

In this study, there are 4 suffixes that belong only to inflectional morpheme, namely prefix $\{-\bar{e}\},\{-\partial\},\{-\Lambda \mathrm{y}\}$, and $\{-\operatorname{In}\}$.

\section{Inflectional suffix $\{-\overline{\mathrm{e}}\}$}

Suffix $\{-\overline{\mathrm{e}}\}$ belongs to inflectional suffix.

$$
\begin{aligned}
& \mathrm{b} \Lambda \ni \eta(\mathrm{N})+\overline{\mathrm{e}} \\
& \text { "the neck" }
\end{aligned} \quad \begin{aligned}
& \mathrm{b} \Lambda \supset \eta \overline{\mathrm{e}}(\mathrm{N}) \\
& \text { "the neck" }
\end{aligned}
$$

The stem $\{\mathrm{b} \Lambda$ $\mathrm{y}\}$ means 'neck' $(\mathrm{N})$. After adding the suffix $\{-\overline{\mathrm{e}}\}$, the meaning of the stem is 'the neck'. Basically, there is no different meaning between the word ' $\mathrm{b} \Lambda \supset$ ' and 'bıэye'. However, those words have a different context of used. The word 'bı⿰习' is usually used as a general term of neck as the part of body. On the other hand, the word 'bıэje' is more specific about which or whose neck that is pointed or discussed. In this case, the function of suffix $\{-\bar{e}\}$ is to indicate the specific part which is discussed. Afterwards, there is no different word class of those stems.

\section{Inflectional suffix $\{-\partial\}$}

Suffix $\{-ə\}$ belongs to inflectional suffix.

$$
\begin{aligned}
& \operatorname{dim} \wedge n(\mathrm{~V})+\partial \rightarrow \text { dimınə (V) } \\
& \text { "kiss" "kiss" }
\end{aligned}
$$

The stem $\{\operatorname{dim} \wedge \mathrm{n}\}$ means 'kiss' (V). After adding the suffix $\{-\partial\}$, the meaning of the stem is 'kiss'. Basically, there is no different meaning between the word 'dimın' and 'dimınə'. However, those words have a different context of used. The word 'dimın' is usually used as a command and in interrogative sentence. On the other hand, the word 'dimınə' is used as a passive voice. In this case, the function of suffix $\{-\partial\}$ is to indicate the passive voice. Looking at the word class, there is no difference between the word 'dimın' and 'dimınə'; they are Verb.

\section{Inflectional suffix $\{-\Lambda \mathrm{\eta}\}$}

Suffix $\{-\Lambda \eta\}$ has two forms when it is 
attached to a stem .

a) The suffix $\{-\wedge \mathrm{y}\}$ does not change the form of the stem .

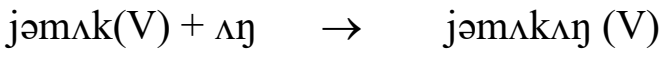

$$
\begin{aligned}
& \text { "take" "take" }
\end{aligned}
$$

The stem $\{j ə m \wedge k\}$ means 'take' (V). Basically, there is no different meaning between the word 'jəmık' and 'jəm $\wedge$ kı ’'. However, those words have a different context of used. The word 'jomık' is usually used as a command. On the other hand, the word 'jəmıkıy' is used as request to take something. In this case, the function of suffix $\{-\vartheta\}$ is to indicate a request.

b). The suffix $\{-\Lambda \mathrm{y}\}$ changes the form of the stem.

$$
\begin{aligned}
& \operatorname{nig} 2 \mathrm{~V}(\mathrm{~V})+\Lambda \mathrm{y} \rightarrow \operatorname{ni\eta ә\Lambda \eta ~(V)~} \\
& \text { "hear" "hear" }
\end{aligned}
$$

The stem \{ninəh\} means 'hear' (V). The suffix $\{-\Lambda \mathrm{y}\}$ assimilates the stem and it

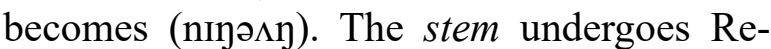
gresive Assimilation.Basically, there is no different meaning between the word 'ninəh' and 'ninəsy'. However, those words have a different context of used. The word 'ninəh' refers to the ability to hear in general. On the other hand, the word 'ninə^n' refers to the activity of hearing with full of attention.

\section{Inflectional suffux $\{-$ In $\}$}

Suffix $\{-$ In $\}$ belongs to inflectional suffix. Suffix $\{-\mathrm{In}\}$ has two forms when it is attached to a stem.

a). The suffix $\{-\operatorname{In}\}$ does not change the form of the stem

$$
\begin{aligned}
& \text { yəlin (V) + In } \rightarrow \text { yəlının(V) } \\
& \text { "cry" "cry" }
\end{aligned}
$$

The stem \{yəlıy means 'cry' (V). After adding the suffix $\{\mathrm{In}\}$, the meaning of the stem is 'cry' (V). Basically, there is no different meaning between the word 'yəlin' and 'yəlının'. However, those words have a different context of used. The word 'yəlinin' means that the subject cries to someone or something. In this case, the function of suffix $\{\mathrm{In}\}$ is emphasizing the meaning of the stem.

b). The suffix $\{-\operatorname{In}\}$ changes the form of the stem.

$$
\begin{aligned}
& \text { t } \Lambda \mathrm{mb} \text { hh (V) }+\mathrm{In} \rightarrow \quad \text { t } \wedge \mathrm{mb} \Lambda \mathrm{In}(\mathrm{V}) \\
& \text { "add" "add" }
\end{aligned}
$$

The stem is $\{\mathrm{t} \Lambda \mathrm{mb} \Lambda \mathrm{h}\}$ which means 'add' (V). After adding the suffix $\{$-In $\}$, the meaning is 'add' $(\mathrm{V})$ '. The suffix $\{-\mathrm{In}\}$ changes the form of the stem. The stem undergoes Regressive Assimilation. Basically, there is no different meaning between the word ' $t \Lambda \mathrm{mb} \Lambda \mathrm{h}$ ' and 't $\mathrm{m}$ mb $\Lambda \mathrm{In}$ '. However, those words have a different context of used. The word ' $t \Lambda \mathrm{mb} \Lambda \mathrm{h}$ ' only means 'add' without clear understanding about what should be added. On the other hand, the word 't $\Lambda$ mb $\Lambda$ In' means 'add' with clear understanding about what should be added. The word 't $\Lambda$ mbsIn' also means as a command to add something. In this case, the function of suffix $\{\mathrm{In}\}$ is emphasizing the meaning of the stem and indicating a command.

\section{The Prefixes and Suffixes that belong to Derivational and Inflectional Morpheme}

\section{Derivational and Inflectional Prefix}

In this study, there are 3 prefixes that belong to derivational and inflectional morpheme, which are prefix $\{\mathrm{y} \partial-\},\{\mathrm{y}-\}$, and prefix $\{m-\}$.

\section{Derivational and Inflectional Prefix \{nכ-}

Prefix $\{\mathrm{y}-\}$ is categorized into derivational morpheme and inflectional morpheme.

$$
\begin{aligned}
& \text { рə }+\mathrm{r} \Lambda \Lambda \mathrm{b}(\mathrm{N}) \rightarrow \operatorname{yər} \Lambda \Lambda \mathrm{b}(\mathrm{V}) \\
& \text { "roof" "making roof" }
\end{aligned}
$$

The stem $\{\mathrm{r} \Lambda \Lambda \mathrm{b}\}$ means 'roof' $(\mathrm{N})$. Prefix $\{$ nə- $\}$ changes the meaning of the stemfrom "roof" $\rightarrow$ "making roof". At the same time, the prefix $\{y ə-\}$ changes the word class 
from Noun $\rightarrow$ Verb. In this case, the function of prefix $\{y \supset-\}$ is to change the noun into active verb and indicate at making something.

The other form of prefix $\{\mathrm{y} \partial-\}$ is as inflectional prefix.

$$
\begin{aligned}
& \text { yə }+\mathrm{b} \Lambda \mathrm{h}(\mathrm{V}) \rightarrow \quad \text { yəb } \Lambda \mathrm{h}(\mathrm{V}) \\
& \text { "to cut" }
\end{aligned}
$$

The stem $\{\mathrm{b} \Lambda \mathrm{h}\}$ means 'to cut' (V). After adding the prefix $\{y \ni\}$, the meaning of the stem is 'to cut' (V). Basically, there is no different meaning between the word 'b $\mathrm{sh}$ ' and 'yəbıh'. However, those words have a different context of used. The word ' $\mathrm{b} \Lambda \mathrm{h}$ ' is usually used as a command to cut the tree. On the other hand, the word ' $y ə b \Lambda h$ ' is usually used to indicate a process of cutting tree. In this case, the function of prefix $\{\mathrm{y} \partial-\}$ is to indicate an active and continuous process of cutting something.

\section{Derivational and Inflectional Prefix $\{\mathfrak{n}-\}$}

Prefix $\{y-\}$ can be categorized into derivational morpheme and inflectional morpheme.

$$
\begin{aligned}
& \eta+\text { oncəh }(\mathrm{N}) \rightarrow \\
& \text { "urine" }
\end{aligned} \rightarrow \begin{aligned}
& \text { yəncəh }(\mathrm{V}) \\
& \text { "pie" }
\end{aligned}
$$

The stem $\{$ əncəh $\}$ means 'urine' $(\mathrm{N})$. After adding the prefix $\{\mathrm{n}-\}$, the meaning of the stem changes from 'urine' $\rightarrow$ 'pie'. At the same time, the word class changes from Noun $\rightarrow$ Verb. In this case, the function of prefix $\{\mathrm{y}-\}$ is to change the Noun into active Verb.

The other form of prefix $\{\mathrm{y}-\}$ is as inflectional prefix.

$$
\begin{aligned}
& \text { y+potēk }(\mathrm{V}) \rightarrow \text { yətēk }(\mathrm{V}) \\
& \text { "count" }
\end{aligned}
$$

The stem \{pətēk\} means 'to count' (V). The prefix $\{\mathrm{y}\}$ assimilates the stem \{pətēk and it becomes \{yətēk\}. The stem undergoes Progressive Assimilation. There is no different meaning between the words 'pətēk' and 'yətēk'. The word 'pətēk is usually used as a command to count something. However, the word 'yətēk' is usually used to indicate an ac- tivity of counting. In this case, the function of prefix $\{\mathrm{n}-\}$ is to indicate an active activity. Looking at the word class, there is no different between the word 'pətēk' and 'yətēk'; they are Verb

\section{Derivational and Inflectional Prefix $\{\mathbf{m}-\}$}

Prefix $\{\mathrm{m}-\}$ is categorized into derivational morpheme and inflectional morpheme.

$$
\begin{aligned}
& \mathrm{m}+\Lambda \operatorname{səm}(\mathrm{N}) \rightarrow \underset{\text { "tamarind" }}{\mathrm{m} \Lambda \mathrm{s} ə \mathrm{~m}(\mathrm{adj})} \\
& \text { "sour" }
\end{aligned}
$$

The stem $\{\Lambda \mathrm{s} ə \mathrm{~m}\}$ means 'tamarind' $(\mathrm{N})$. The prefix $\{\mathrm{m}\}$ changes the meaningof the stem from "tamarind" $\rightarrow$ "sour". At the same time, the word class changes from Noun $\rightarrow$ Adjective.

The other form of prefix $\{m-\}$ is as inflectional prefix.

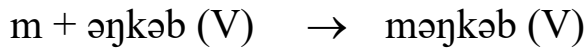

$$
\begin{aligned}
& \text { "hide" "hide" }
\end{aligned}
$$

The stem is $\{$ onkəb\}, the meaning is 'to hide' $(\mathrm{V})$. After adding the prefix $\{\mathrm{m}-\}$, the meaning of the stem becomes 'hide' (V).

\section{Derivational and Inflectional Suffix}

There are 2 suffixes belong to derivational and inflectional morpheme, which are suffix $\{-\Lambda n\}$ and $\{-n\}$.

\section{Derivational and Inflectional Suffix $\{-\Lambda \mathrm{n}\}$}

Suffix $\{-\Lambda \mathrm{n}\}$ can be categorized into derivational morpheme and inflectional morpheme.

$$
\begin{aligned}
& \operatorname{minum}(\mathrm{V})+\Lambda \mathrm{n} \rightarrow \operatorname{minum} \wedge \mathrm{n}(\mathrm{N}) \\
& \text { "to drink" "drink" }
\end{aligned}
$$

The stem \{minum\} means 'drink' (V). After adding the suffix $\{-\Lambda \mathrm{n}\}$, the meaning of the stem changes from 'drink' $\rightarrow$ 'to drink a drink'. At the same time, the word class changes from Verb $\rightarrow$ Noun.

The other form of suffix $\{-\Lambda n\}$ is as inflectional suffix.

$$
\mathrm{p} \Lambda \Lambda \mathrm{k}(\operatorname{Adj})+\Lambda \mathrm{n} \rightarrow \mathrm{p} \Lambda \Lambda \mathrm{k} \Lambda \mathrm{n}(\operatorname{Adj})
$$


"near"

"nearer"

The stem $\{\mathrm{p} \Lambda \Lambda \mathrm{k}\}$ means 'near' (Adj). After adding the suffix $\{-\Lambda \mathrm{n}\}$, the meaning of the stem becomes 'nearer' (Adj). Basically, there is no different meaning between the word 'p $\Lambda_{\Lambda \mathrm{k}}$ ' and ' $\mathrm{p} \Lambda \Lambda \mathrm{k} \Lambda \mathrm{n}$ '. However, those words have a different context of use. The word ' $\mathrm{p} \Lambda \Lambda \mathrm{k}$ ' is usually used to state something which is near without comparing to the other. However, the word 'p $\Lambda \Lambda \mathrm{k} \wedge$ ' is used compare the closeness 2 things. In this case, the function of suffix $\{-\Lambda \mathrm{n}\}$ is to comparing something.

\section{Derivational and Inflectional Suffix $\{-n\}$}

Suffix $\{-n\}$ is categorized into derivational morpheme and inflectional morpheme.

$\mathrm{d} \Lambda \mathrm{kI}($ Adj $)+\mathrm{n} \rightarrow$
"dirty" $\quad \begin{aligned} & \mathrm{d} \Lambda \mathrm{kin}(\mathrm{N}) \\ & \text { "the dust of" }\end{aligned}$

The stem $\{\mathrm{d} \Lambda \mathrm{kI}\}$ means 'dirty' (Adj). The suffix $\{\mathrm{n}\}$ changes the meaning of the stem from 'dirty' $\rightarrow$ 'the dust of'. At the same time, the word class of the stem changes from Adjective $\rightarrow$ Noun. It shows that the function of suffix $\{-n\}$ is to change the Verb into Noun. tional suffix.

The other form of suffix $\{-n\}$ is inflec-

$\operatorname{gIgI}(\mathrm{N})+\mathrm{n}$
"the teeth" $\quad \begin{aligned} & \text { gIgIn }(\mathrm{N}) \\ & \text { "the teeth of" }\end{aligned}$

The stem $\left\{\mathrm{gIg}_{\mathrm{I}}\right\}$ means 'teeth' $(\mathrm{N})$. The suffix $\{n\}$ changes the meaning of the stem becomes 'the teeth of'. Basically, there is no different meaning between the word 'gigI' and 'gigin'. However, those words have a different context of used. The word 'gigi' refers to the teeth as a part of body. However, the word 'gigin' refers to whose teeth that is being discussed. The suffix $\{-n\}$ gives an additional grammatical function as a possessive of something.

\section{CONCLUSION AND SUGGESTION}

Based on the objectives, finding and discussion as stated in the previous chapter, the study concludes that there are nine prefixes and six suffixes of Balinese language spoken by Muslim people in Tegallinggah Village. The nine prefixes are classified into: 2 prefixes $\{m \curvearrowright-\}$ and $\{$ nəy- $\}$ which belong only to derivational morpheme, 4 prefixes $\{\Lambda-\}$, $\{\mathrm{kə}-\}$, $\{\mathrm{b} ə-\}$, and $\{\mathrm{o}-\}$, belong only to inflectional morpheme, 3 prefixes $\{\mathrm{y} \partial-\},\{\mathrm{n}-\}$, and $\{\mathrm{m}-\}$ can belong to derivational and inflectional morpheme. Afterward, the six suffixes are classified into; there is no suffix which belong only to derivational morpheme, 4 suffixes $\{-\overline{\mathrm{e}}\},\{-\partial\},\{-\Lambda \mathrm{y}\}$, and $\{-\mathrm{In}\}$ belong only to inflectional morpheme, 2 suffixes $\{-\Lambda \mathrm{n}\}$, dan $\{-\mathrm{n}\}$ can belong to derivational and inflectional morpheme.

This study limited in term of data size and analysis due to time constraint and number of sources. For these reasons further study should address the combination between prefix and suffix spoken by Muslim people in this village. The other researcher can conduct a study in comparing the number and the function of prefix and suffix that is used in 2 different villages with a huge population of Muslim people. Through conducting those researches, the phenomena related to the Morphological system of Balinese language can be explained and captured scientifically with a reliable data. It can be a source for the other researcher.

\section{REFERENCES}

Bawa, I W. and Jendra, I W. 1981. Struktur Bahasa Bali. Pusat Pembinaan dan pengembangan Bahasa Jakarta: Departemen Pendidikan dan Kebudayaan.

Bogdan, R. C., \& Biklen, S. K. 2007. Qualitative Research for Education. Boston: Pearson.

Carstairs, McCarthy. 2002. An Introduction to English Morphology: Words and Their Structure. Edinburgh: Edinburgh University Press Ltd 22 George Square.

Cohen, R., Story, J., \& Moon, N. 2015. The Impact of Diaspora. United Kingdom: Oxford Diasporas Programme.

Erlina, N. 2017. Prefixes and Suffixes of Balinese 
Language Spoken in Penyabangan Village. JurnalPendidikanBahasaInggrisUndiksha.

Flores, G. S. 2006. Language, Dialect, and Register: Sociolinguistics and the Estimation of Measurement Error in the Testing of English Language Learners. Teachers College Record, 2354-2379.

Keraf. G. 1973. Tata Bahasa Indonesia. Flores: Nusa Indah

Kracht, M. 2007. Introduction to Linguistics. Los Angeles: Department ofLinguistics, UCLA

Kusuma, P. E. 2013. Affixation of Tigawasa Dialect. Jurnal Pendidikan Bahasa Inggris .

Miles, M.B \& Huberman, A. M., 1984. Drawing Valid Meaning from Qualitative Data. Educational Research. 20-30.

Putra, I. K. 2013. Affixation of Cempaga Dialect. Jurnal Pendidikan Bahasa Inggris .

Rickford, J. R., Sweetland, J. \& Rickford, A. E. 2004. African American English and other Vernaculars in Education:A TopicCoded Bibliography. Journal of English Linguistics DOI:10.1177/007542420426 8226,32-230.

Roach. P. 1991. English Phonetics and Phonology. Cambridge: Cambridge University Press

Samarin, W. J. 1967. Field Linguistics A Guide to Linguistic Field Work. USA: Holt, Rinehart and Winston, Inc.

Seken, I K. 2017. Introduction to Linguistics. Depok : Rajawali Pers.

Sudarma, I. K. 2016. Affixation of Pacung Dialect: A Descriptive Study. Jurnal Pendidikan Bahasa Inggris Undiksha.

Surada, I. M. 2015. Sanskrit' Influence in Balinese Language. Discovery , 22-28.

Tegegne, W. 2015. The Use of Dialects in Education and Its Impacts on Students' Learning and Achievements. Education Journal, doi:10.11648/j.edu.20150405.222 63-269.

Trudgill, P. 1974. Sociolinguistics An Introduction to language and Sociaty. Britain: Penguin Book.

Utami, N. N. T. 2013. An Analysis od Derivational and Inflectional Morphemes of Tenganan Pegringsingan Dialect. Jurnal Pendidikan Bahasa Inggris Undiksha .

Wagner, L., Clopper, C. G., \& Pate, J. K. 2014. Children's perception of dialect variation. Journal of Child Language. DOI: 10.101/S0305000913000330,1062-1084.

Wiweka, I Wayan Adi. 2014. Inflectional and
Derivational Morphemes of Pelaga Dialect: A Descriptive Qualitative Study. JurnalPendidikanBahasaInggrisUndiksha. Yule, G. 2006. The Study of Language 3rd Edition. New York: Cambridge University Pres 